\title{
Bacillus herbersteinensis sp. nov.
}

\section{Correspondence Hans-Jürgen Busse hans-juergen.busse@ vu-wien.ac.at}

\section{Monika Wieser, ${ }^{1}$ Hanna Worliczek, ${ }^{1}$ Peter Kämpfer ${ }^{2}$ and Hans-Jürgen Busse ${ }^{1}$}

\author{
${ }^{1}$ Institut für Bakteriologie, Mykologie und Hygiene, Veterinärmedizinische Universität Wien, \\ A-1210 Wien, Austria \\ ${ }^{2}$ Institut für Angewandte Mikrobiologie, Justus-Liebig-Universität, Heinrich-Buff-Ring 26-32, \\ D-35392 Giessen, Germany
}

Two bacterial strains, designated $D-1,5 a^{\top}$ and $D-1,5 b$, were isolated from a medieval wall painting in the chapel of Castle Herberstein, Styria (Austria). The Gram-positive, heterotrophic, aerobic, spore-forming rods showed nearly identical whole-cell protein patterns, identical genomic fingerprints and identical physiological profiles, demonstrating their relationship at the species level. Both strains contained meso-diaminopimelic acid in their peptidoglycan, possessed a quinone system comprising menaquinone MK-7 and had fatty acid profiles in which $\mathrm{C}_{15: 0}$ iso and $\mathrm{C}_{15: 0}$ anteiso were predominant. The $16 \mathrm{~S}$ rRNA gene sequence of $\mathrm{D}-1,5 \mathrm{a}^{\top}$ showed the highest similarity (99.5\%) to the sequence of Bacillus sp. LMG 20243, and Bacillus flexus IFO $15715^{\top}$ was the next most closely related established species (96.5\%). Other type strains, such as Bacillus fastidiosus DSM $91^{\top}$, Bacillus indicus SD $/ 3^{\top}$, Bacillus cibi JG- $30^{\top}$, Bacillus megaterium IAM $13418^{\top}$, Bacillus cohnii DSM $6308^{\top}$, Bacillus bataviensis LMG $21833^{\top}$ and Bacillus soli LMG $21838^{\top}$, shared $96 \cdot 0-96 \cdot 1 \% 16 \mathrm{~S}$ rRNA gene sequence similarity with $\mathrm{D}-1,5 \mathrm{a}^{\top}$. The combination of physiological and chemotaxonomic traits distinguishes the two strains from those species sharing the highest sequence similarities (96.0-96.5\%). On the basis of these characteristics and the phylogenetic position of strain D-1,5a $a^{\top}\left(=\mathrm{DSM} 16534^{\top}=\mathrm{CCM} 7228^{\top}\right)$, this strain is assigned as the type strain of a novel species of the genus Bacillus, for which the name Bacillus herbersteinensis sp. nov. is proposed.
From microbiological examinations of a medieval wall painting in the chapel of Castle Herberstein in Styria (Austria), several bacterial strains have been isolated and classified as novel species, including Agrococcus citreus, Micrococcus luteus (Wieser et al., 1999, 2002), Brachybacterium fresconis, Brachybacterium sacelli, Halomonas muralis, Bacillus decolorationis, Virgibacillus picturae and Brevibacterium picturae (Heyrman et al., 2002a, b, 2003a, b, 2004). During our studies of the microbiological diversity of the wall painting, we isolated, in addition to $A$. citreus and M. luteus, other isolates, which were preliminarily identified as members of the Bacillaceae (four isolates), the Microbacteriaceae (one isolate) and the Moraxellaceae (one isolate) (M. Wieser, unpublished results). Here we report the detailed characterization of two strains from this collection, which, in preliminary examinations, differed

Published online ahead of print on 13 May 2005 as DOI 10.1099/ ijs.0.63660-0.

Abbreviations: pNA, p-nitroanilide; pNP, $p$-nitrophenyl.

The GenBank/EMBL/DDBJ accession number for the $16 \mathrm{~S}$ rRNA gene sequence of $D-1,5 a^{\top}$ is AJ781029.

Genomic fingerprints and polar lipid profiles of strains $D-1,5 a^{\top}$ and $\mathrm{D}-1,5 \mathrm{~b}$ are available as supplementary figures in IJSEM Online. by only a single band in the protein patterns after SDS-PAGE (results not shown) performed as described by Altenburger et al. (1996).

Strains were isolated and investigated morphologically as described by Wieser et al. (1999). $\mathrm{NaCl}$ tolerance was tested on PYES agar $(0 \cdot 3 \%$ peptone, $0 \cdot 3 \%$ yeast extract, $0.23 \%$ disodium succinate, $1 \cdot 5 \%$ agar, $\mathrm{pH} 7 \cdot 2$ ) supplemented with $1,3,5,7$ and $10 \% \mathrm{NaCl}$, respectively. Tolerance towards different $\mathrm{pH}$ values was examined on PYES agar adjusted with $\mathrm{HCl}(37 \%)$ or $4 \mathrm{M} \mathrm{NaOH}$ to $\mathrm{pH} 6,7,8,9,10,11$ and 12 , respectively, or on buffered medium as described by Nielsen et al. (1995). Hydrolysis of starch was examined on PYES medium as described by Sneath (1986). Other tests were done as described by Kämpfer et al. (1991). Optimal growth was obtained on PYES agar or broth, $\mathrm{pH} 8 \cdot 0$, supplemented with $1 \% \mathrm{NaCl}(\mathrm{w} / \mathrm{v})$. The characteristics are listed in the species description below and in Table 1.

Identical genomic fingerprints (see Supplementary Fig. S1 available in IJSEM Online) of strains D-1,5a $\mathrm{a}^{\mathrm{T}}$ and D1,5b obtained after enterobacterial repetitive intergenic consensus (ERIC) sequence PCR (Wieser \& Busse, 2000) confirmed indications from protein patterns (results not shown) that these strains were members of a single species. 
Table 1. Characteristics that differentiate Bacillus herbersteinensis sp. nov. from Bacillus species that share the highest $16 \mathrm{~S}$ rRNA gene sequence similarity $(\geqslant 96 \%)$

Species: 1, B. herbersteinensis sp. nov. (data from this study); 2, B. bataviensis (Heyrman et al., 2004); 3, B. cibi (Yoon et al., 2005); 4, B. cohnii (Priest et al., 1988; Täubel et al., 2003; Suresh et al., 2004); 5, B. fastidiosus (Claus \& Berkeley, 1986); 6, B. flexus (Priest et al., 1988; Täubel et al., 2003; Suresh et al., 2004); 7, B. indicus (Suresh et al., 2004); 8, B. megaterium (Priest et al., 1988; Täubel et al., 2003; Suresh et al., 2004); 9, B. soli (Heyrman et al., 2004). +, Positive; -, negative; W, weakly positive; v, variable; NG, no growth; NA, not analysed.

\begin{tabular}{|c|c|c|c|c|c|c|c|c|c|}
\hline Characteristic & 1 & 2 & 3 & 4 & 5 & 6 & 7 & 8 & 9 \\
\hline Sporangium shape & Unswollen & $\begin{array}{l}\text { Slightly } \\
\text { swollen }\end{array}$ & Swollen & Swollen & Unswollen & NA & $\begin{array}{l}\text { Slightly } \\
\text { swollen }\end{array}$ & Swollen & $\begin{array}{l}\text { Slightly } \\
\text { swollen }\end{array}$ \\
\hline pH tolerance ${ }^{*}$ & $7-12$ & $\begin{array}{c}6-9 \cdot 5 \\
(>4-<10)\end{array}$ & $\begin{array}{c}5 \cdot 5-7 \cdot 5 \\
(>5)\end{array}$ & $5(<10)$ & NA & $4 \cdot 5-9 \cdot 5$ & $6-7$ & $4 \cdot 5-9 \cdot 5$ & $\begin{array}{c}5-9 \\
(>4-<9 \cdot 5)\end{array}$ \\
\hline $\mathrm{NaCl}(\%)$ tolerance ${ }^{*}$ & $0-5(<7)$ & NA & $0-12$ & $0-10(\mathrm{~W})$ & $0-5(<7)$ & $0-10(\mathrm{w})$ & $0-2$ & $0-5(<10)$ & NA \\
\hline $\begin{array}{l}\text { Temperature tolerance } \\
\left({ }^{\circ} \mathrm{C}\right)^{\star}\end{array}$ & $\begin{array}{c}4-28 \\
(<37)\end{array}$ & $\begin{array}{l}<30-50 \\
(<55)\end{array}$ & $\begin{array}{c}10-40 \\
(>4-<50)\end{array}$ & $\begin{array}{l}10-47 \\
(<49)\end{array}$ & $\begin{array}{c}10-40 \\
(>5-<50)\end{array}$ & $\begin{array}{c}17-40 \\
(>5-<50)\end{array}$ & $\begin{array}{l}15-37 \\
(<40)\end{array}$ & $\begin{array}{c}5(\mathrm{~V})-40 \\
(\mathrm{~V})\end{array}$ & $\begin{array}{c}<30->45 \\
(<50)\end{array}$ \\
\hline Nitrate reduction & - & + & - & + & - & - & - & - & + \\
\hline Starch hydrolysis & + & NA & + & + & - & + & NA & + & NA \\
\hline \multicolumn{10}{|l|}{ Acid production from: } \\
\hline Salicin & - & $\mathrm{W}$ & NA & NA & NA & $\mathrm{V}$ & NA & + & - \\
\hline D-Mannose & - & $\mathrm{V}$ & + & - & NA & - & + & $\mathrm{V}$ & + \\
\hline $\mathrm{N}$-Acetylglucosamine & - & + & NA & NA & NA & NA & NA & NA & + \\
\hline D-Glucose & - & + & + & - & NG & + & - & + & + \\
\hline Maltose & - & + & + & NA & NA & + & NA & + & + \\
\hline Trehalose & - & $\mathrm{V}$ & + & NA & NA & + & NA & + & + \\
\hline L-Arabinose & - & - & - & NA & NG & NA & NA & $\mathrm{V}$ & - \\
\hline D-Mannitol & - & + & - & $\mathrm{NA}$ & NG & + & - & $\mathrm{V}$ & - \\
\hline D-Xylose & - & - & - & - & NG & - & - & $\mathrm{V}$ & - \\
\hline \multicolumn{10}{|l|}{ Assimilation of: } \\
\hline D-Cellobiose & + & NA & + & - & NA & + & + & - & NA \\
\hline D-Glucose & + & $\mathrm{NA}$ & + & - & NA & + & NA & + & NA \\
\hline D-Melibiose & + & NA & NA & - & NA & - & + & - & NA \\
\hline D-Sucrose & + & NA & + & - & NA & + & + & - & NA \\
\hline D-Trehalose & + & NA & + & NA & NA & + & NA & + & NA \\
\hline Citrate & + & - & - & - & $\mathrm{NA}$ & + & - & + & - \\
\hline Major fatty acids & $\begin{array}{l}\text { ai- } C_{15: 0} \\
i-C_{15: 0}\end{array}$ & $\begin{array}{l}\mathrm{i}-\mathrm{C}_{15: 0} \\
\text { ai- } \mathrm{C}_{15: 0}\end{array}$ & $\begin{array}{l}\mathrm{i}-\mathrm{C}_{15: 0} \\
\mathrm{i}-\mathrm{C}_{14: 0}\end{array}$ & $\begin{array}{l}\text { ai- } C_{17: 0}, \mathrm{i}-\mathrm{C}_{15: 0} \\
\text { ai- } \mathrm{C}_{15: 0} \text { or } \\
\mathrm{i}-\mathrm{C}_{15: 0}, \text { ai- } \mathrm{C}_{15: 0}\end{array}$ & NA & $\begin{array}{l}\text { ai- } \mathrm{C}_{15: 0} \\
\mathrm{i}-\mathrm{C}_{15: 0}\end{array}$ & $\begin{array}{l}\mathrm{i}-\mathrm{C}_{15: 0} \\
\text { ai- } \mathrm{C}_{15: 0}\end{array}$ & ai- $C_{15: 0}$ & $\begin{array}{l}\text { i- } C_{15: 0} \\
\text { ai- } C_{15: 0}\end{array}$ \\
\hline $\begin{array}{l}\text { Glycolipids (GLs) } \\
\text { present }\end{array}$ & 2 GLs & NA & NA & - & NA & - & - & - & NA \\
\hline $\begin{array}{l}\text { Cell-wall diamino } \\
\text { acid } \dagger\end{array}$ & $m \mathrm{Dpm}$ & NA & NA & Orn & NA & $m \mathrm{Dpm}$ & L-Orn & $m \mathrm{Dpm}$ & NA \\
\hline
\end{tabular}

${ }^{*}$ Values in parentheses indicate conditions under which no growth was observed.

$\dagger m \mathrm{Dpm}$, meso-Diaminopimelic acid; Orn, ornithine.

The 16S rRNA gene sequence (1464 bases) of D-1,5a $\mathrm{a}^{\mathrm{T}}$ was analysed and sequenced according to Wieser et al. (1999), using primers 27f, 342f, 519r and 1992r (Lane, 1991). It should be mentioned here that sequencing of the 16S rRNAencoding gene of $\mathrm{D}-1,5 \mathrm{a}^{\mathrm{T}}$ caused unexpected problems. When primer $27 \mathrm{f}$ was used, the sequence could be determined only up to position 192. Ambiguous results were obtained for subsequent bases. A similar observation was made at the same position in the sequence when primer 519r was employed, and the base at position 193 (A or G) could not be determined in either of the two sequencing directions. This observation might be explained by the presence of two rRNA-encoding genes in $\mathrm{D}-1,5 \mathrm{a}^{\mathrm{T}}$, one of which contains a gap or insertion at this position. Sequence comparisons (Pearson \& Lipman, 1988) revealed the highest scores with the type strains of established species Bacillus flexus IFO $15715^{\mathrm{T}}(96 \cdot 5 \%)$, Bacillus fastidiosus DSM $91^{\mathrm{T}}$ $(96 \cdot 1 \%)$, Bacillus indicus $\mathrm{SD} / 3^{\mathrm{T}}(96 \cdot 1 \%)$, Bacillus cibi JG$30^{\mathrm{T}}(96 \cdot 0 \%)$, Bacillus megaterium IAM $13418^{\mathrm{T}}(96 \cdot 0 \%)$, Bacillus cohnii DSM $6308^{\mathrm{T}}(96 \cdot 0 \%)$, Bacillus bataviensis LMG $21833^{\mathrm{T}}(96 \cdot 0 \%)$, Bacillus soli LMG $21838^{\mathrm{T}}(96 \cdot 0 \%)$, Bacillus asahii MA001 ${ }^{\mathrm{T}}(95 \cdot 8 \%)$, Bacillus muralis LMG 
$20238^{\mathrm{T}}(95 \cdot 8 \%)$, Bacillus novalis LMG $21837^{\mathrm{T}}(95 \cdot 7 \%)$, Bacillus niacini IFO $15566^{\mathrm{T}}(95 \cdot 7 \%)$ and Bacillus firmus IAM $12464^{\mathrm{T}}(95 \cdot 6 \%)$, indicating no relatedness between $\mathrm{D}$ $1,5 \mathrm{a}^{\mathrm{T}}$ and any of them at the species level. Interestingly, the $16 \mathrm{~S}$ rRNA gene sequence of $\mathrm{D}-1,5 \mathrm{a}^{\mathrm{T}}$ shared the highest similarity $(99 \cdot 5 \%)$ with the sequence of Bacillus sp. LMG 20243, which was recently isolated from a mural painting in St. Martins church in Greene-Kreiensen (Lower Saxony, Germany; Gorbushina et al., 2004) and shared 97.1\% similarity with Bacillus sp. LMG 19415, which, like D-1,5a ${ }^{\mathrm{T}}$, had been isolated from the wall painting in the chapel of Castle Herberstein (Gurtner et al., 2000). The phylogenetic position of strain $D-1,5 \mathrm{a}^{\mathrm{T}}$ was calculated using the PHYLIP software package (Felsenstein, 1993) after alignment of the $16 \mathrm{~S}$ rRNA gene sequences using CLUSTAL $\mathrm{X}$ (Thompson et al., 1997) and manual editing of sequences for ambiguous nucleotides and gaps using BioEdit (Hall, 1999). In all algorithms, the phylogenetically next most closely related species to strain $\mathrm{D}-1,5 \mathrm{a}^{\mathrm{T}}$ were (i) the type strain of the type species of the genus Bacillus, Bacillus subtilis DSM $10^{\mathrm{T}}$ (Fig. 1), although the two strains share only $95.3 \% 16 \mathrm{~S}$ rRNA gene sequence similarity, and (ii) Bacillus fastidiosus DSM $91^{\mathrm{T}}$. This branching was statistically supported by a moderate bootstrap value $(81 \%)$. However, these results indicate that strain $\mathrm{D}-1,5 \mathrm{a}^{\mathrm{T}}$ may be considered as a species of the genus Bacillus sensu stricto. For $\mathrm{G}+\mathrm{C}$ content

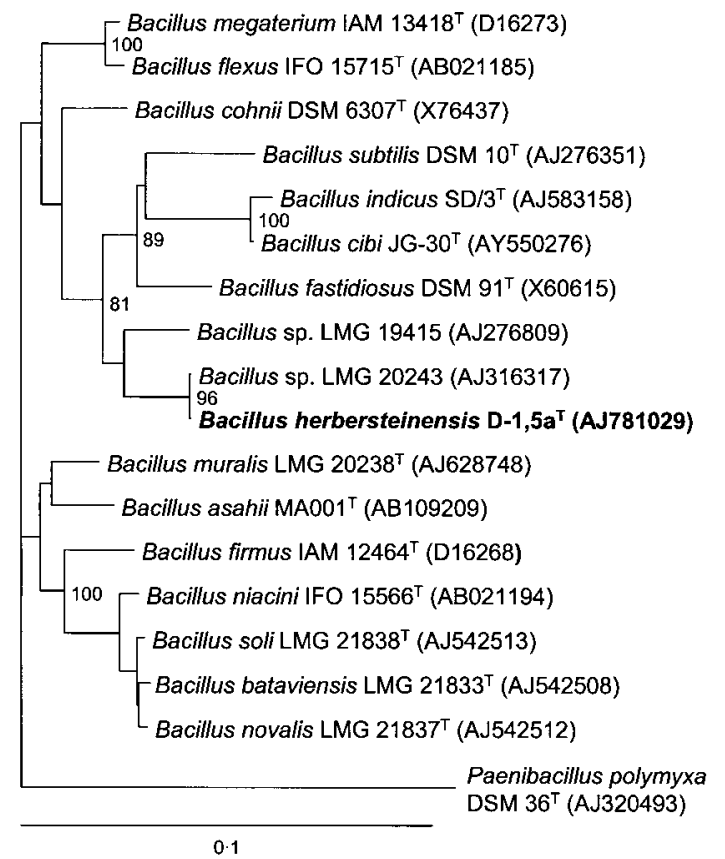

Fig. 1. Maximum-likelihood phylogenetic tree showing the position of strain $D-1,5 a^{\top}$ among other Bacillus species on the basis of $16 \mathrm{~S}$ rRNA gene sequences. Bootstrap values (expressed as percentages of 100 replications) greater than $70 \%$ are shown at branching points. Bar, $10 \%$ sequence divergence. The tree was rooted using Paenibacillus polymyxa DSM $36^{\top}$ as an outgroup. determination, DNA was extracted and purified as described by Auling et al. (1985). The DNA G + C contents of strains $\mathrm{D}-1,5 \mathrm{a}^{\mathrm{T}}$ and D1,5b were determined by HPLC (Kaneko et al., 1986) as $36 \cdot 2$ and $36 \cdot 9 \mathrm{~mol} \%$, respectively. These values differ only slightly from those reported for Bacillus fastidiosus (34.3-35.1 mol\%; Claus \& Berkeley, 1986), Bacillus flexus (37.0-37.9 mol\%; Priest et al., 1988), Bacillus megaterium (37.3 mol\%; Claus \& Berkeley, 1986) and Bacillus niacini (37.0-39.0 mol\%; Nagel \& Andreesen, 1991).

Isoprenoid quinones and polar lipids were extracted and analysed as described previously (Tindall, 1990; Ventosa et al., 1993; Altenburger et al., 1996). Fatty acid methyl esters were extracted from biomass grown on nutrient agar $\left(1^{-1}\right.$; $5 \mathrm{~g}$ peptone from casein, $3 \mathrm{~g}$ meat extract, $3 \mathrm{~g}$ yeast extract, $15 \mathrm{~g}$ agar) and was analysed as described by Kämpfer (1994). The diagnostic cell-wall diamino acid was determined as described by Schleifer (1985).

The major respiratory menaquinone in the two strains was found to be MK-7 and the diagnostic diamino acid in their cell walls was meso-diaminopimelic acid. These characteristics are in agreement with those of numerous species of the genus Bacillus, including the type species, Bacillus subtilis (Claus \& Berkeley, 1986). The polar lipid profiles of D-1,5a $\mathrm{a}^{\mathrm{T}}$ (see Supplementary Fig. S2 in IJSEM Online) and D1,5b (results not shown) were identical. Major to moderate amounts of diphosphatidylglycerol, phosphatidylglycerol, two unknown glycolipids, which might correspond to monoglucosyl diacylglycerol and diglucosyldiacyl glycerol (as reported to be present in a strain of Geobacillus stearothermophilus; Minnikin et al., 1974), and moderate to minor amounts of two unknown phospholipids and two unknown polar lipids were detected. The presence of two glycolipids and the absence of phosphatidylethanolamine clearly distinguish the two strains from Bacillus flexus DSM $1320^{\mathrm{T}}$, Bacillus cohnii LMG $16678^{\mathrm{T}}$ and Bacillus megaterium DSM $32^{\mathrm{T}}$ (Täubel et al., 2003). On the other hand, the presence of the two glycolipids might confirm the closer phylogenetic relatedness to Bacillus subtilis (Fig. 1), which has been reported to contain glycolipids (Brundish et al., 1965; Bishop et al., 1967). The fatty acid profiles of strains D-1,5 $\mathrm{a}^{\mathrm{T}}$ and D1,5b contained the major compounds $\mathrm{C}_{15: 0}$ iso, $\mathrm{C}_{15: 0}$ anteiso, $\mathrm{C}_{14: 0}$ iso, $\mathrm{C}_{16: 0}$ iso, $\mathrm{C}_{16: 0}$ and $\mathrm{C}_{17: 0}$ iso, which are characteristic of numerous taxa within the bacilli (Kämpfer, 1994). The relative fatty acid concentrations are listed below in the species description.

All of the characteristics determined for strain D-1,5 $\mathrm{a}^{\mathrm{T}}$ are in accordance with those of the genus Bacillus. On the basis of phylogenetic distance from established Bacillus species, also indicated by relatively low $16 \mathrm{~S}$ rRNA gene sequence similarities $(<97 \%)$ and the combination of unique phenotypic characteristics, it is demonstrable that $\mathrm{D}-1,5 \mathrm{a}^{\mathrm{T}}$ is not affiliated with any species of this genus. In conclusion, we describe $D-1,5 \mathrm{a}^{\mathrm{T}}$ as the type strain of a novel species, for which we propose the name Bacillus herbersteinensis sp. nov. 


\section{Description of Bacillus herbersteinensis sp. nov.}

Bacillus herbersteinensis (her.ber.stein' en.sis. N.L. masc. adj. herbersteinensis pertaining to Castle Herberstein in Styria, in which the chapel with the medieval wall painting is located from which the type strain was isolated).

Cells are motile, rod-shaped, Gram-positive in the $\mathrm{KOH}$ and aminopeptidase tests, rod-shaped and produce oval spores in terminal, unswollen sporangia. Colonies on PYES agar are $2-3 \mathrm{~mm}$ in diameter, slightly raised, irregular and cream-coloured to beige. Older colonies are more translucent. Catalase- and oxidase-positive. Growth occurs at 4 and $28{ }^{\circ} \mathrm{C}$, in the presence of $0,1,3$ and $5 \% \mathrm{NaCl}(\mathrm{w} / \mathrm{v})$ but not at 7 or $10 \% \mathrm{NaCl}(\mathrm{w} / \mathrm{v})$. On buffered medium, growth is observed at pH 7 (weakly), 8 and 9. On unbuffered medium, growth is observed at $\mathrm{pH} 7$ (weakly), 8, 9, 10, 11 and 12 but not at $\mathrm{pH}$ 6. Negative for nitrate reduction and haemolysis. Starch, $p$-nitrophenyl (pNP) $\beta$-D-galactopyranoside, $\mathrm{pNP} \alpha$ D-glucopyranoside, pNP $\beta$-D-glucopyranoside and bis-pNP phosphate are hydrolysed. pNP $\beta$-D-xyloside, pNP phenylphosphonate, pNP phosphorylcholine, 2-deoxythymidine$5^{\prime}$-pNP phosphate, L-alanine pNA (pNA, $p$-nitroanilide), L-glutamate $\gamma$-3-carboxy-pNA, L-proline pNA and pNP $\beta$ D-glucoronide are not hydrolysed. Acid is not produced from adonitol, L-arabinose, D-arabitol, cellobiose, dulcitol, erythritol, glucose, inositol, lactose, maltose, D-mannitol, Dmannose, melibiose, methyl D-glucoside, raffinose, rhamnose, salicin, sorbitol, sucrose, trehalose or D-xylose. $\mathrm{N}$ Acetyl-D-glucosamine, L-arabinose (weakly), p-arbutin (weakly), D-cellobiose, D-fructose, D-galactose, gluconic acid, D-glucose, D-maltose, D-mannitol, D-mannose, $\alpha$-D-melibiose, L-rhamnose, D-ribose, salicin, D-sorbitol, D-sucrose, D-trehalose, D-xylose, acetate (weakly), cisaconitate (weakly), L-aspartate, citrate, fumarate, DL-3hydroxybutyrate, DL-lactate, L-malate, L-ornithine (weakly), 2-oxoglutarate (weakly), pyruvate and L-proline are assimilated. Adonitol, $i$-inositol, maltitol, putrescine, azelate, glutarate, itaconate, trans-aconitate, adipate, propionate, 4-aminobutyric acid, 4-hydroxybenzoic acid, mesaconate, suberate, L-alanine, $\beta$-alanine, L-serine, L-histidine, Lleucine, L-phenylalanine, L-tryptophan, 3-hydroxybenzoic acid and phenylacetate are not assimilated. The fatty acid profile consists of $\mathrm{C}_{14: 0}$ iso $(8 \cdot 7-14 \cdot 2 \%), \mathrm{C}_{14: 0}(0-0 \cdot 5 \%)$, $\mathrm{C}_{15: 0}$ iso $(17 \cdot 7-27 \cdot 4 \%), \mathrm{C}_{15: 0}$ anteiso $(17 \cdot 0-23 \cdot 4 \%), \mathrm{C}_{15: 0}$ $(1 \cdot 9-3 \cdot 2 \%), \mathrm{C}_{16: 1} \omega 7 c(2 \cdot 9-5 \cdot 1 \%), \mathrm{C}_{16: 1} \omega 11 c(1 \cdot 9-2 \cdot 4 \%)$, $\mathrm{C}_{16: 0}$ iso $(8 \cdot 4-15 \cdot 8 \%), \mathrm{C}_{16: 0}(4 \cdot 8-5 \cdot 9 \%), \mathrm{C}_{17: 1} \omega 10 c$ iso $(2 \cdot 4-2 \cdot 5 \%), \mathrm{C}_{17: 1} \omega 5 \mathrm{c}$ iso $(1 \cdot 0 \%), \mathrm{C}_{17: 0}$ iso $(3 \cdot 7-5 \cdot 1 \%)$, $\mathrm{C}_{17: 0}$ anteiso $(1 \cdot 1-1 \cdot 2 \%)$ and $\mathrm{C}_{17: 0}(1 \cdot 1-1 \cdot 6 \%)$. The diamino acid in the cell wall is meso-diaminopimelic acid. The predominant polar lipids are diphosphatidylglycerol, phosphatidylglycerol and an unidentified glycolipid. Additionally, moderate to minor amounts of a second unknown glycolipid, two phospholipids and four polar lipids are present. The major respiratory quinone is MK-7. The DNA $\mathrm{G}+\mathrm{C}$ content is $36 \cdot 2-36 \cdot 9 \mathrm{~mol} \%$ (HPLC).

The type strain is strain D-1,5 $\mathrm{a}^{\mathrm{T}}\left(=\mathrm{DSM} 16534^{\mathrm{T}}=\mathrm{CCM}\right.$ $\left.7228^{\mathrm{T}}\right)$. Strains $\mathrm{D}-1,5 \mathrm{a}^{\mathrm{T}}$ and $\mathrm{D}-1,5 \mathrm{~b}$ were both isolated from a damaged wall painting in the chapel of Castle Herberstein, Styria (Austria).

\section{Acknowledgements}

This work was supported by grants from the Austrian Science Foundation (FWF), projects P09099-MOB and P10730-MOB. We greatly appreciate the help of J. Euzéby with nomenclatural problems.

\section{References}

Altenburger, P., Kämpfer, P., Makristathis, A., Lubitz, W. \& Busse, H.-J. (1996). Classification of bacteria isolated from a medieval wall painting. J Biotechnol 47, 39-52.

Auling, G., Probst, A. \& Kroppenstedt, R. M. (1985). Chemo- and molecular taxonomy of $\mathrm{D}(-)$-tartrate-utilizing pseudomonads. Syst Appl Microbiol 8, 114-120.

Bishop, D. G., Rutberg, L. \& Samuelsson, B. (1967). The chemical composition of the cytoplasmic membrane of Bacillus subtilis. Eur J Biochem 2, 448-453.

Brundish, D. E., Shaw, N. \& Baddiley, J. (1965). The occurrence of glycolipids in Gram-positive bacteria. Biochem J 95, 21c-22c.

Claus, D. \& Berkeley, R. C. W. (1986). Genus Bacillus Cohn 1872. In Bergey's Manual of Systematic Bacteriology, vol. 2, pp. 1105-1140. Edited by P. H. A. Sneath, N. S. Mair, M. E. Sharpe \& J. G. Holt. Baltimore: Williams \& Wilkins.

Felsenstein, J. (1993). PHYLIP (phylogeny inference package), version 3.5c. Distributed by the author. Department of Genome Sciences, University of Washington, Seattle, USA.

Gorbushina, A. A., Heyrman, J., Dornieden, T., Gonzalez-Delvalle, M., Krumbein, W. E., Laiz, L., Petersen, K., Saiz-Jiminez, C. \& Swings, J. (2004). Bacterial and fungal diversity and biodeterioration problems in mural painting environments of St. Martins church (Greene-Kreiensen, Germany). Int Biodeter Biodegradation 53, 13-24.

Gurtner, C., Heyrman, J., Piñar, G., Lubitz, W., Swings, J. \& Rölleke, S. (2000). Comparative analyses of the bacterial diversity on two different biodeteriorated wall paintings by DGGE and 16S rDNA sequence analysis. Int Biodeter Biodegradation 46, 229-239.

Hall, T. A. (1999). BIOEDIT: a user-friendly biological sequence alignment editor and analysis program for Windows 95/98/NT. Nucleic Acids Symp Ser 41, 95-98.

Heyrman, J., Balcaen, A., De Vos, P., Schumann, P. \& Swings, J. (2002a). Brachybacterium fresconis sp. nov. and Brachybacterium sacelli sp. nov., isolated from deteriorated parts of a medieval wall painting of the chapel of Castle Herberstein (Austria). Int J Syst Evol Microbiol 52, 1641-1646.

Heyrman, J., Balcaen, A., De Vos, P. \& Swings, J. (2002b). Halomonas muralis sp. nov., isolated from microbial biofilms colonizing the walls and murals of the Saint-Catherine chapel (Castle Herberstein, Austria). Int J Syst Evol Microbiol 52, 2049-2054.

Heyrman, J., Balcaen, A., Rodriguez-Diaz, M., Logan, N. A., Swings, J. \& De Vos, P. (2003a). Bacillus decolorationis sp. nov., isolated from biodeteriorated parts of the mural paintings at the Servilia tomb (Roman necropolis of Carmona, Spain) and the Saint-Catherine chapel (Castle Herberstein, Austria). Int J Syst Evol Microbiol 53, 459-463.

Heyrman, J., Logan, N. A., Busse, H.-J., Balcaen, A., Lebbe, L., Rodriguez-Diaz, M., Swings, J. \& De Vos, P. (2003b). Virgibacillus carmonensis sp. nov., Virgibacillus necropolis sp. nov. and Virgibacillus picturae sp. nov., three novel species isolated from deteriorated mural paintings, transfer of the species of the genus Salibacillus to Virgibacillus, as Virgibacillus marismortui comb. nov. 
and Virgibacillus salexigens comb. nov., and emended description of the genus Virgibacillus. Int J Syst Evol Microbiol 53, 501-511.

Heyrman, J., Vanparys, B., Logan, N. A., Balcaen, A., RodriguezDiaz, M., Felske, A. \& De Vos, P. (2004). Bacillus novalis sp. nov., Bacillus vireti sp. nov., Bacillus soli sp. nov., Bacillus bataviensis sp. nov. and Bacillus drentensis sp. nov., from the Drentse A grasslands. Int J Syst Evol Microbiol 54, 47-57.

Kämpfer, P. (1994). Limits and possibilities of total fatty acid analysis for classification and identification of Bacillus species. Syst Appl Microbiol 17, 86-98.

Kämpfer, P., Steiof, M. \& Dott, W. (1991). Microbiological characterization of a fuel-oil contaminated site including numerical identification of heterotrophic water and soil bacteria. Microb Ecol 21, 227-251.

Kaneko, T., Katoh, K., Fujimoto, M., Kumagi, M., Tamaoka, J. \& Katayama-Fujimura, Y. (1986). Determination of the nucleotide composition of a deoxyribonucleic acid by high-performance liquid chromatography of its enzymatic hydrolysates: a review. J Microbiol Methods 4, 229-240.

Lane, D. J. (1991). 16S/23S rRNA sequencing. In Nucleic Acid Techniques in Bacterial Systematics, pp. 115-175. Edited by E. Stackebrandt \& M. Goodfellow. Chichester: Wiley.

Minnikin, D. E., Abdolrahimzadeh, H. \& Baddiley, J. (1974). The occurrence of phosphatidylethanolamine and glycosyl diglycerides in thermophilic bacilli. J Gen Microbiol 83, 415-418.

Nagel, M. \& Andreesen, J. R. (1991). Bacillus niacini sp. nov., a nicotinate-metabolizing mesophile isolated from soil. Int $J$ Syst Bacteriol 41, 134-139.

Nielsen, P., Fritze, D. \& Priest, F. G. (1995). Phenetic diversity of alkaliphilic Bacillus strains: proposal for nine new species. Microbiology 141, 1745-1761.

Pearson, W. R. \& Lipman, D. J. (1988). Improved tools for biological sequence comparison. Proc Natl Acad Sci U S A 85, 2444-2448.

Priest, F. G., Goodfellow, M. \& Todd, C. (1988). A numerical classification of the genus Bacillus. J Gen Microbiol 134, 1847-1882.
Schleifer, K.-H. (1985). Analysis of the chemical composition and primary structure of murein. Methods Microbiol 18, 123-156.

Sneath, P. H. A. (1986). Endospore-forming gram-positive rods and cocci. In Bergey's Manual of Systematic Bacteriology, vol. 2, pp. 1104-1207. Edited by S. T. Williams, M. E. Sharpe \& J. G. Holt. Baltimore: Williams \& Wilkins.

Suresh, K., Prabagaran, S. R., Sengupta, S. \& Shivaji, S. (2004). Bacillus indicus sp. nov., an arsenic-resistant bacterium isolated from an aquifer in West Bengal, India. Int J Syst Evol Microbiol 54, 1369-1375.

Täubel, M., Kämpfer, P., Buczolits, S., Lubitz, W. \& Busse, H.-J. (2003). Bacillus barbaricus sp. nov., isolated from an experimental wall painting. Int J Syst Evol Microbiol 53, 725-730.

Thompson, J. D., Gibson, T. J., Plewniak, F., Jeanmougin, F. \& Higgins, D. G. (1997). The CLUSTAL_X Windows interface: flexible strategies for multiple sequence alignment aided by quality analysis tools. Nucleic Acids Res 25, 4876-4882.

Tindall, B. J. (1990). Lipid composition of Halobacterium lacusprofundi. FEMS Microbiol Lett 66, 199-202.

Ventosa, A., Marquez, M. C., Kocur, M. \& Tindall, B. J. (1993). Comparative study of "Micrococcus sp." strains CCM 168 and CCM 1405 and members of the genus Salinicoccus. Int J Syst Bacteriol 43, 245-248.

Wieser, M. \& Busse, H.-J. (2000). Rapid identification of Staphylococcus epidermidis. Int J Syst Evol Microbiol 50, 1087-1093.

Wieser, M., Schumann, P., Martin, K., Altenburger, P., Burghardt, J., Lubitz, W. \& Busse, H.-J. (1999). Agrococcus citreus sp. nov., isolated from a medieval wall painting of the chapel of Castle Herberstein (Austria). Int J Syst Bacteriol 49, 1165-1170.

Wieser, M., Denner, E. M. B., Kämpfer, P. \& 10 other authors (2002). Emended descriptions of the genus Micrococcus, Micrococcus luteus (Cohn 1872) and Micrococcus lylae (Kloos et al. 1974). Int J Syst Evol Microbiol 52, 629-637.

Yoon, J.-H., Lee, C.-H. \& Oh, T.-K. (2005). Bacillus cibi sp. nov., isolated from jeotgal, a traditional Korean fermented seafood. Int J Syst Evol Microbiol 55, 733-736. 